\title{
Histomorphometric and immunohistochemical changes in interstitial cells and ovarian follicles of rats treated with metformin during and after induction of permanent estrus
}

\author{
Alterações histomorfométricas e imunohistoquímicas em células intersticiais e folícullos ovarianos \\ de ratas tratadas com metformina durante e após a indução do estro permanente \\ Cambios histomorfométricos e inmunohistoquímicos en células intersticiales y folículos ováricos de \\ ratas tratadas con metformina durante y después de la inducción del estro permanente
}

Leonardo Augusto Lombardi ORCID: https://orcid.org/0000-0002-9735-8804 Universidade Federal do Triângulo Mineiro, Brazil E-mail: nda_leo@yahoo.com.br

Leandro Sabará Mattos ORCID: https://orcid.org/0000-0003-3041-7344 Universidade Nove de Julho, Brazil E-mail: leomattos1984@gmail.com

Marcio Luis Alves Moura ORCID: https://orcid.org/ 0000-0003-3276-9861 Universidade Cruzeiro do Sul, Brazil

E-mail: mouramarciomoura@gmail.com

Ana Paula Espindula ORCID: https://orcid.org/0000-0002-9282-4482 Universidade Federal do Triângulo Mineiro, Brazil E-mail: ana.espindula@uftm.edu.br

Ricardo Santos Simões

ORCID: https://orcid.org/0000-0002-6689-8832 Universidade de São Paulo, Brazil

E-mail: mjsimoes_43@hotmail.com

Rinaldo Florencio-Silva

ORCID: https://orcid.org/0000-0002-2956-6230 Universidade de Federal de São Paulo, Brazil E-mail: rinaldohisto.cell@gmail.com

Manuel de Jesus Simões

ORCID: https://orcid.org/0000-0003-2770-8618

Universidade de Federal de São Paulo, Brazil

E-mail: manuel.morf@epm.br

Paulo Celso Franco

ORCID: https://orcid.org/0000-0002-6372-1492

Universidade de Federal de São Paulo, Brazil E-mail: paulinho.morf@yahoo.com.br

Gisela Rodrigues da Silva Sasso

ORCID: https://orcid.org/0000-0002-6583-1329

Universidade de Federal de São Paulo, Brazil E-mail: gisela.morf@gmail.com José Maria Soares-Jr

ORCID: https://orcid.org/0000-0003-0774-9404 Universidade de São Paulo, Brazil E-mail: jsoares415@hotmail.com

\begin{abstract}
Objective: To evaluate the histomorphometric and immunohistochemical changes in interstitial cells and ovarian follicles of rats treated with metformin during and after induction of permanent estrus. Methods: Thirty-two adultfemale rats with regular estrous cycle were equally divided into four groups: 1) GCtrl - at estrous phase. 2) GPCOS at permanent-estrous phase. 3) GMet1 - rats and daily treated with metformin $(12.5 \mathrm{mg} / \mathrm{Kg})$ during 60 consecutive days, as preventive form and 4) GMet2 - PCOS rats, which remained exposed to 60 days of continuous illumination and treated with metformin. After that, the animals were euthanized, and the ovaries were removed and processed for paraffin embedding. Sections were stained with H.E. for histomorphometry or subjected to immunohistochemistry for
\end{abstract}


Ki-67 and cleaved caspase-3 (Casp-3) detections. Results: The GPCOS showed lack of corpus luteum and several ovarian cysts, as well as interstitial-like cells. The presence of corpus luteum and a significant increase in primary and antral follicles were observed in Mel-treated groups, which also showed a decrease in the number of ovarian cysts and in the area occupied by interstitial-like cells. The presence of corpus luteum along with an increase in the number of primary follicles in the Met 2 group were noticed $(\mathrm{p}<0,01)$. A significant reduction in number of cysts and in the area occupied by interstitial cells, as well as a decrease in nuclear volume of interstitial cells, were noticed in the Mettreated groups, mainly in the Met2 group. The percentage of cell proliferation was significantly higher in granulosa cells of the Met-treated groups than PCOS group, mainly in the GMet2 ( $<<0,01)$, which was similar to the GCtrl group. On the other hand, the percentage of apoptosis (cleaved-caspase-3-positive cells) was significantly higher in the granulosa cells of GPCOS and Met-treated groups than the GCtrl group, but without significant difference, which showed weak cleaved caspase-3 immunoreactivity in those cells. Conclusion: The ovaries of rats treated with metformin showed a decrease in nuclear volume and in the area occupied by interstitial cells, presence of corpus luteum, in addition to a decrease in the number of cysts.

Keywords: Interstitial cells; Ovarian follicles; Metformin; Rats.

\section{Resumo}

Objetivo: Avaliar as alterações histomorfométricas e imunohistoquímicas em células intersticiais e folículos ovarianos de ratas tratadas com metformina durante e após a indução do estro permanente. Métodos: Trinta e duas ratas adultas com ciclo estral regular foram divididas igualmente em quatro grupos: 1) GCtrl - na fase de estro. 2) GPCOS - na fase de estro permanente. 3) GMet1 - ratos e ratos tratados diariamente com metformina $(12,5 \mathrm{mg} / \mathrm{Kg})$ durante 60 dias consecutivos, como forma preventiva e 4) GMet2 - ratos com SOP, que permaneceram expostos a 60 dias de iluminação contínua e tratados com metformina. Em seguida, os animais foram sacrificados e os ovários removidos e processados para inclusão em parafina. As seções foram coradas com H.E. para histomorfometria ou submetido a imunohistoquímica para detecção de Ki-67 e caspase-3 clivada (Casp-3). Resultados: O GPCOS mostrou ausência de corpo lúteo e vários cistos ovarianos, além de células intersticiais. A presença de corpo lúteo e um aumento significativo de folículos primários e antrais foram observados nos grupos tratados com Mel, que também mostraram uma diminuição no número de cistos ovarianos na área ocupada por células do tipo intersticial. Foi observada a presença de corpo lúteo junto com um aumento no número de folículos primários no grupo Met2 (p<0,01). Uma redução significativa no número de cistos e na área ocupada por células intersticiais, bem como uma diminuição no volume nuclear das células intersticiais, foram observadas nos grupos tratados com Met, principalmente no grupo Met2 $(\mathrm{p}<0,01)$. A porcentagem de proliferação celular foi significativamente maior nas células da granulosa dos grupos tratados com Met do que no grupo PCOS, principalmente no GMet2 $(\mathrm{p}<0.01)$, que foi semelhante ao grupo GCtrl. Por outro lado, a porcentagem de apoptose (células positivas para caspase-3 clivada) foi significativamente maior nas células da granulosa dos grupos tratados com GPCOS e Met do que no grupo GCtrl, porém sem diferença significativa, que apresentou imunorreatividade fraca para caspase-3 clivada nessas células. Conclusão: Os ovários de ratas tratadas com metformina apresentaram diminuição do volume nuclear e da área ocupada pelas células intersticiais, presença de corpo lúteo, além de diminuição do número de cistos.

Palavras-chave: Células intersticiais; Folículos ovarianos; Metformina; Ratas.

\section{Resumen}

Objetivo: Evaluar los cambios histomorfométricos e inmunohistoquímicos en células intersticiales y folículos ováricos de ratas tratadas con metformina durante y después de la inducción del estro permanente. Métodos: Treinta y dos ratas adultas con un ciclo estral regular se dividieron por igual en cuatro grupos: 1) GCtrl - en la fase estral. 2) GPCOS - en la fase de estro permanente. 3) GMet1 - ratas y ratas tratadas diariamente con metformina $(12,5 \mathrm{mg} / \mathrm{kg})$ durante 60 días consecutivos, como forma preventiva; y 4) GMet2 - ratas con SOPQ, que permanecieron expuestas a 60 días de iluminación continua y tratadas con metformina. Luego, se sacrificaron los animales y se extrajeron los ovarios y se procesaron para su inclusión en parafina. Las secciones se tiñeron con H.E. para histomorfometría o se sometieron a inmunohistoquímica para detectar Ki-67 y caspasa-3 escindida (Casp-3). Resultados: El GPCOS mostró ausencia de cuerpo lúteo y varios quistes ováricos, además de células intersticiales. Se observó la presencia de cuerpo lúteo y un aumento significativo de folículos primarios y antrales en los grupos tratados con Mel, que también mostraron una disminución en el número de quistes ováricos y en el área ocupada por células intersticiales. Se observó la presencia de cuerpo lúteo junto con un aumento en el número de folículos primarios en el grupo Met2 $(\mathrm{p}<0,01)$. Se observó una reducción significativa en el número de quistes y en el área ocupada por las células intersticiales, así como una disminución en el volumen nuclear de las células intersticiales, en los grupos tratados con Met, principalmente en el grupo Met2. El porcentaje de proliferación celular fue significativamente mayor en las células de la granulosa de los grupos tratados con Met que en el grupo PCOS, principalmente en GMet2 ( $\mathrm{p}<0,01$ ), que fue similar al grupo GCtr1. Por otro lado, el porcentaje de apoptosis (células positivas para caspasa-3 escindida) fue significativamente mayor en las células de la granulosa de los grupos tratados con GPCOS y Met que en el grupo GCtrl, pero sin diferencia significativa, que presentó inmunorreactividad débil para caspasa-3 escindida en estos. células. Conclusión: Los ovarios de ratas tratadas con metformina mostraron una disminución en el volumen nuclear y 
en el área ocupada por las células intersticiales, la presencia de un cuerpo lúteo, además de una disminución en el número de quistes.

Palabras clave: Células intersticiales; Folículos ováricos; Metformina; Ratas.

\section{Introduction}

Among several causes of infertility, PCOS stands out due to its frequency as it affects nearly 5\% to $10 \%$ of women during reproductive life (Goodarzi et al., 2010; Batista et al., 2012). Several animal models have been developed to mimic PCOS, among which stands out PCOS induction by means of continuous illumination exposure. This induces the animal to an estrous-permanent condition, associated with anovulation, presence of multiple cysts, and increase in androgens and estrogens serum levels, along with the reduction in melatonin synthesis (Sara et al., 2012). PCOS in its classic form associated with obesity, anovulation, and hyperandrogenism, represents the most common cause of anovulatory infertility (Qiao, Wang \& $\mathrm{Li}$, 2008; Tamimi et al., 2009; Zabuliene L \& Tutkuviene, 2010). Excessive concentration of androgens may inhibit the emergence of a dominant follicle and induce follicular atresia. That condition disrupts the normal menstrual cycle, which in turn promote a hyperandrogenic state and chronic anovulation.

A previous study from our group showed that interstitial cells exhibited high immunoexpression of enzymes related to serum levels of estradiol and testosterone in PCOS rats (Lombardi et al., 2014). In an earlier study of our group, it was reported an increase in the area occupied by interstitial cells and lack of corpus luteum, in ovaries of a rat model of PCOS induced by continuous light exposure. It was suggested that those interstitial cells may have originated from ovarian cysts of the PCOS rats, due to the degeneration of granulosa cells and the differentiation of theca interna cells (Lombardi et al., 2012).

Although PCOS etiology remains controversial, it has been suggested an association between PCOS and metabolic disturbances such as hyperinsulinemia and insulin resistance. Under abnormal high concentration, insulin binds to insulin-like growth factor-1 receptor (IGF-1R), which is highly distributed in ovarian tissue. Then, when insulin receptors are blocked or their concentrations are low, insulin binds to IGF-1R in theca cells, leading to androgen synthesis (Speroff \& Fritz, 2005). Meanwhile, IGF-1R is diminished in granulosa cells and increased in theca cells of women with PCOS, thus contributing to hyperandrogenism (Smaniotto \& Simões, 1996). Various authors have described the efficacy of infertility treatment with insulin sensitizers such as metformin (Maciel et al., 2004; Speroff \& Fritz, 2005; Mahamed et al., 2011). The reduced peripheral insulin resistance in PCOS subjects after metformin use leads to a decrease in hyperinsulinemia, which interrupts the mechanism that trigger hyperandrogenism in those patients (Speroff \& Fritz, 2005).

Thus, this study aims to investigate the histomorphometric and immunohistochemical changes in interstitial cells and ovarian follicles of rats treated with metformin during and after induction of permanent estrus.

\section{Methodology}

This prospective experimental study used thirty-two three-moths-old virgins female rats (Rattus norvegicus albinus) with $\pm 250 \mathrm{~g}$ of body weight mass, purchased from the Center for the Development of Experimental Models (CEDEME) at the São Paulo School of medicine, Federal University of São Paulo (UNIFESP/ EPM). This study was initially approved by the Research Ethics Committee at UNIFESP/EPM (Report $n^{\circ}$ 0179/12), following the guidelines of the Canadian Council on Animal Care (Olfert, Cross \& Mcwilliam AA, 1993)

After an adaptation period of one week to the local animal facility, all animals were subjected to daily collection of vaginal secretions for seven consecutive days in order to evaluate ovarian function. Through the result of this examination it was possible to observe regular estrous cycles, demonstrating normal ovarian functions. Only rats with regular estrous cycles were included in the study. Afterwards, the rats were randomly divided into four groups. Thirty-two adult-female rats with regular estrous cycle 
were equally divided into four groups: 1) GCtrl - at physiological-estrous phase. 2) GPCOS - at permanent-estrous phase induced by 60 days of continuous illumination (rats with PCOS). 3) GMet1 - PCOS rats and daily treated with metformin (12.5 mg/Kg) during 60 consecutive days, as preventive form, and 4) GMet2 - PCOS rats, which remained exposed to 60 days of continuous illumination and treated with metformin (Speroff \& Fritz, 2005). It is noteworthy that the animals of the GMet2 group remained under continuous illumination during a total period of 120 days (60 first days for the induction of the estrous-permanent condition and more 60 days during treatment period). To obtain animals with PCOS, the rats were placed in wooden boxes, kept in a vivarium under continuous artificial lighting using lamps (Philips, Daylight Model, 40W) that provided about 400 Lux in the region occupied by the rats over a period of 60 consecutive days. The GPCOS animals remained in the same standard vivarium conditions, however, with the lighting period from 7 a.m to 7 p.m. Thereafter, collection of vaginal secretions for seven consecutive days was carried out again, in order to analyze the phases of estrous cycle. Then, only the animals of the GCtrl that showed regular estrous cycle, as well as the ones of the GPCOS group that was at estrous-permanent condition was used.

Thereafter, the animals were anesthetized with an intraperitoneal injection of $15 \mathrm{mg} / \mathrm{kg}$ xylazine hydrochloride (Rompun ${ }^{\circledR}$, SP, Brazil) associated with $30 \mathrm{mg} / \mathrm{kg}$ ketamine hydrochloride (Ketalar ${ }^{\circledR}, \mathrm{SP}$, Brazil), and placed in a supine position. Subsequently, after a longitudinal median incision made at the abdomen, the ovaries were carefully removed and immediately fixed for $24 \mathrm{~h}$ at room temperature (RT) in $10 \%$ formaline solution, buffered with $0.1 \mathrm{M}$ sodium phosphate at $\mathrm{pH}$ 7.2. After the removal of the ovaries, the animals were euthanized by deepening the plane of anesthesia and disposed of in accordance with current standards at the São Paulo School of medicine (UNIFESP/EPM). After formaline fixation, the ovaries were processed for paraffin embedding. By using a microtome (Minot), $5 \mu \mathrm{m}$-thick sections were obtained from the blocks, with a distance of at least $50 \mu \mathrm{m}$ from each sections. Sections were collected on histological slides and subsequently stained with hematoxylin and eosin (HE), whereas others sections were subjected to immunohistochemical methods.

\section{Morphological and morphometric analyses}

The evaluation of the slides was carried out at the laboratory of Histology/ UNIFESP/EPM. For the quantification of the parameters evaluated, images were captured by using a high-resolution camera (AxioCam-MCR, Carl Zeiss) adapted to a light microscope (Axiolab, Carl Zeiss) at x400 magnification, which were transmitted to a computer with AxioVision Rel 4.2 software (Carl Zeiss). For the estimation of nuclear volumes of interstitial cells, 10 images in each ovary of each rat was obtained, comprising 80 images per group. Subsequently, the lower and the larger diameter of 10 cells/images were measured and applied to the following formula: $\mathrm{v}=\mathrm{a}^{2} \cdot \mathrm{b} / 1.91$ wherein $\mathrm{a}=$ lower diameter and $\mathrm{b}=$ larger diameter, whereas 1.91 represents a constant (Lombardi et al., 2012). The determination of the occupied area by interstitial cells was expressed as percentage, under objective lenses of 10x. Initially the ovarian total area and the area occupied by interstitial cells in 10 slices of each ovary/animal were measured. Then, the proportion of the area occupied by interstitial cells in relation to the ovarian total area was calculated as percentage in each section. In this same magnification the number of ovarian follicles presented in 10 sections in each ovary/animal was counted, and classified as primary and antral follicles.

\section{Immunohistochemical analysis}

Immunohistochemical reactions for the detection of $\mathrm{Ki}-67$ and cleaved caspase-3 were carried out to analyse cell proliferation and apoptosis, respectively (Lombardi et al., 2014) Therefore, sections were collected on silanized slides and subsequently dewaxed in xylene and hydrated in decreasing concentrations of ethanol. The endogenous peroxidase activity was blocked by incubating sections with 3\% hydrogen peroxide for 5 minutes. After washings, the sections were incubated in a sodium citrate buffer ( $\mathrm{pH} \mathrm{6.0),} 10 \mathrm{mM}$ at $95^{\circ} \mathrm{C}$ for 20 minutes. The non-specific binding sites were blocked with $2 \%$ PBS-BSA for 1 hour. Sections were then incubated at $4^{\circ} \mathrm{C}$ in a humidified chamber overnight in the anti-Ki-67 (MIB-5, Dako, Denmark, United 
Kingdom) and anti-cleaved caspase-3 (Asp175-antibody \#9661, Cell Signaling Technology, Beverly, USA) primary antibodies, both at 1:100 dilution. Subsequently, sections were washed and incubated in the biotinylated goat anti-mouse/rabbit secondary antibody (Ig, Duet kit Dako). The reactions were revealed with the streptavidin-peroxidase system (Dako Cytomation, USA) using 3,3'-diamino-benzidine (DAB) as a chromogen. The sections were subsequently counter-stained with hematoxylin. As a negative control, sections were incubated with non-specific immunoglobulin (DAKO Cytomation, USA) in place of the primary antibody. The frequency of Ki-67 and cleaved caspase-3 immunollabeled cells were expressed as percentage (\%); at least 500 cells/animal were counted.

\section{Statistical analysis}

Quantitative data were expressed as Mean \pm standard deviation and subjected to one-way analysis of variance (ANOVA) followed by Tukey test, using the "Grafpad 5 Prism" software. The rejection level for the null hypothesis was set at $1 \%(\mathrm{p}<0,01)$ indicating significant values with an asterisk.

\section{Results}

\section{Morphological and morphometric analyses}

The morphological results showed the lack of corpus luteum and the presence of multiple ovarian cysts in the GPCOS group. Numerous groups of cells containing large and bulky nuclei with well-evident nucleoli, grouped as spherical and cord-like structures with epithelioid aspect, which are typical characteristics of interstitial cells, were also observed in the GPCOS group (Fig.1). On the other hand, the presence of corpus luteum in the Met-treated groups along with an increase in the number of primary follicles in the Met2 group were noticed (Fig.1 and Table 1). A significant reduction in number of cysts and in the area occupied by interstitial cells, as well as a decrease in nuclear volume of interstitial cells, were noticed in the Met-treated groups, mainly in the Met2 group $(\mathrm{p}<0,01)$ (Table 1$)$. 
Figure 1. Photomicrographs of H.E stained sections of ovarian regions from all groups. (A) Note a portion of a corpus luteum (CL) and a mature antral follicle (arrow) of the Met1 group; (B) observe the presence of a cyst (C) and a portion of a corpus luteum of the Met2 group; note in $\mathbf{C}$ the presence of interstitial cells (CI) of the PCOS group.

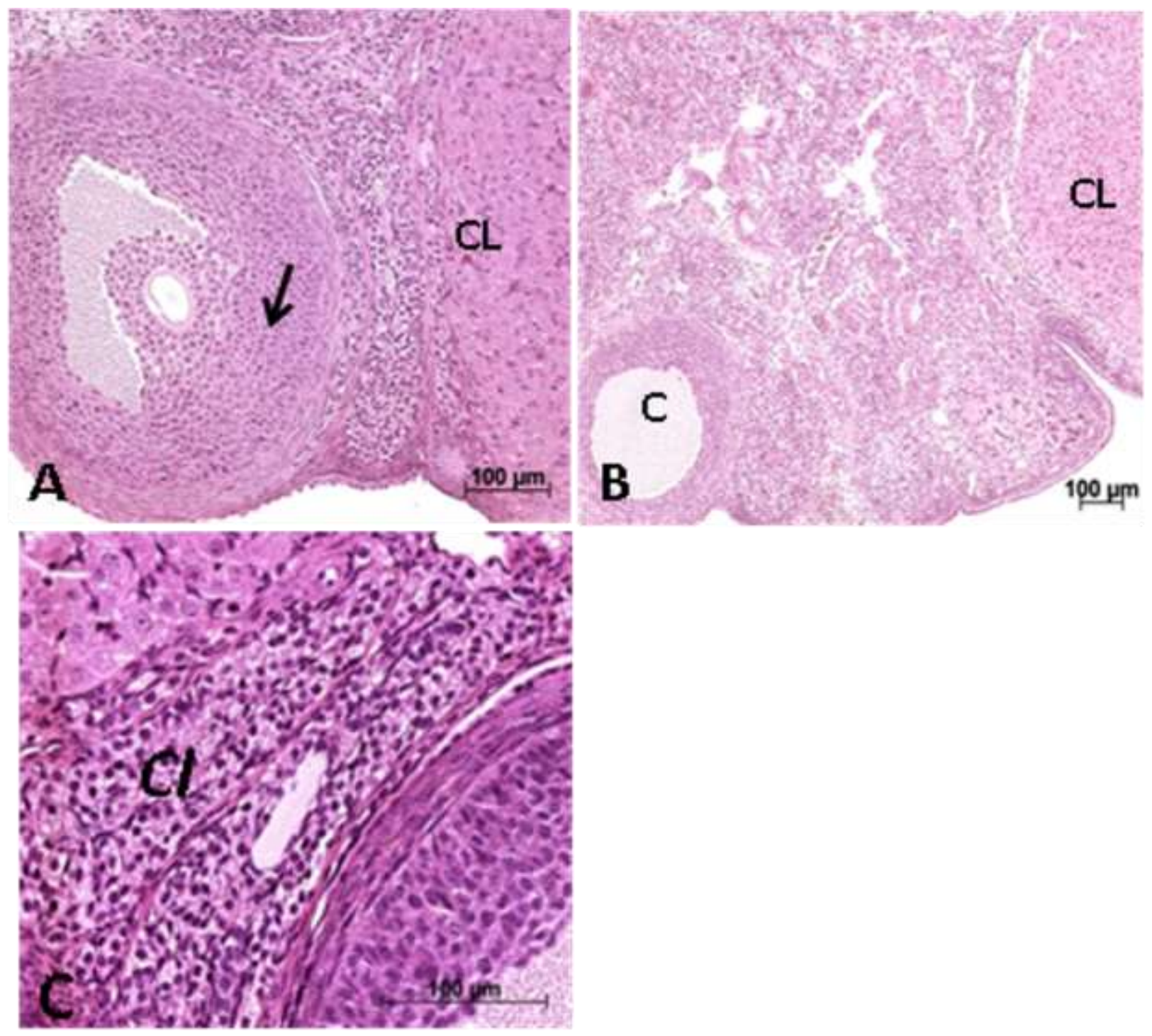

Source: Authors. 
Table 1. Mean and Standard deviation $(\mathrm{M} \pm \mathrm{SD})$ of the morphological and morphometric parameters obtained in the ovaries of estrous-permanent rats (GPCOS), rats with normal estrous cycle (GCtrl), Met-treated rats as preventive (GMet1) and treatment (GMet2) forms.

\begin{tabular}{|c|c|c|c|c|}
\hline Parameters & $\begin{array}{l}\text { GCtrl } \\
\mathrm{N}: 8\end{array}$ & $\begin{array}{l}\text { GPCOS } \\
\mathrm{N}: 8\end{array}$ & $\begin{array}{l}\text { GMet1 } \\
\text { N: } 8\end{array}$ & $\begin{array}{l}\text { GMet2 } \\
\text { N: } 8\end{array}$ \\
\hline $\mathrm{N}^{0}$ Cysts/Ovary & 0 & $5.50 \pm 0.36$ & $3 \pm 0,2$ & $4 \pm 0,15$ \\
\hline $\mathrm{N}^{0}$ Corpus luteum/Ovary & $4.61 \pm 0.80$ & 0 & $1,75 \pm 0,12$ & $1,75 \pm 0,15$ \\
\hline $\mathrm{N}^{0}$ Primary follicles $/ 0.04 \mathrm{~mm}^{2}$ & $32.15 \pm 0.15$ & $20.88 \pm 0.89$ & $5,75 \pm 1,99$ & $23,8 \pm 0,99^{*}$ \\
\hline $\mathrm{N}^{0}$ Antral follicles $/ 0.59 \mathrm{~mm}^{2}$ & $4.45 \pm 0.65$ & $1.02 \pm 0.03$ & $0,75 \pm 0,18$ & $0,35 \pm 0,06$ \\
\hline$\%$ Area of Interstitial Cells & $19.33 \pm 1.07$ & $52.11 \pm 1.03$ & $34,70 \pm 2,66$ & $20,16 \pm 0,47^{*}$ \\
\hline Nuclear volume of Interstitial Cells $/ \mu \mathrm{m}^{3}$ & $7.40 \pm 0.83$ & $15.40 \pm 1.37$ & $11,43 \pm 0,4$ & $10,13 \pm 1,46$ \\
\hline
\end{tabular}

Asterisks indicate differences statistically significant $(\mathrm{p}<0.01)$, in comparison to GPCOS. N: Number of rats in each group. Source: Authors.

\section{Immunohistochemical analysis}

The percentage of apoptosis (cleaved-caspase-3- positive cells) was significantly higher in the granulosa cells of GPCOS and Met-treated groups than the GCtrl group, which showed weak cleaved caspase-3 immunoreactivity in those cells ( $<<0,01$ ). In addition, a weak and non-significant cleaved caspase-3 immunoreactivity was noticed in the theca cells and interstitial cells of all groups (table 2). Meanwhile, cell proliferation (\% of Ki-67-positive cells) was significantly higher in granulosa cells of the Mettreated groups than PCOS group, mainly in the GMet2 ( $<<0,01)$, which was similar to the GCtrl group. A weak and not significant $\mathrm{Ki}-67$ immunostaining in the theca cells, as well as absence of cell proliferation in interstitial cells of all groups, were also observed (Table 2).

Table 2. Mean and Standard deviation $(\mathrm{M} \pm \mathrm{SD})$ expressed as percentage $(\%)$ of immunostained cells from ovaries of estrouspermanent rats (GPCOS), rats with normal estrous cycle (GCtrl), Met-treated rats as preventive (GMet1) and treatment (GMet2) forms.

\begin{tabular}{lllll}
\hline Parameters & GCtrl & GPCOS & GMet1 & GMet2 \\
N: 8 & N: 8 & N: 8 & N: 8 \\
\hline \% Apoptosis of theca cells & $0.01 \pm 0.02$ & $0.02 \pm 0.01$ & $0.01 \pm 0.03$ & $0.01 \pm 0.01$ \\
\hline \% Apoptosis of granulosa cells & $1.50 \pm 0.02$ & $89.05 \pm 7.80$ & $87,5 \pm 7,8$ & $88,11 \pm 2,8$ \\
\hline \% Apoptosis of interstitial cells & $0.15 \pm 0.62$ & $2.20 \pm 0.50$ & $2.10 \pm 0.43$ & $2.02 \pm 0.57$ \\
\hline \% Proliferation of theca cells & $2.01 \pm 0.12$ & $2.05 \pm 0.12$ & $2.03 \pm 0.15$ & $2.02 \pm 0.14$ \\
\hline$\%$ Proliferation of granulosa cells & $95.05 \pm 0.20$ & $5.07 \pm 0.18$ & $28,07 \pm 0,27$ & $91,5 \pm 0,23 *$ \\
\hline$\%$ Proliferation of interstitial cells & 0 & 0 & 0 & 0 \\
\hline
\end{tabular}

Asterisks indicate differences statistically significant $(\mathrm{p}<0.01)$, in comparison to GPCOS. N: Number of rats in each group. Source: Authors.

\section{Discussion}

Metformin (dimethylbiguanide) is an oral hypoglycemic agent derived from guanidine used in the treatment of type 2 diabetes (Mathur et al., 2014). This drug promotes an increase in peripheral insulin sensitivity and cell metabolism of glucose. It also acts by reducing hepatic gluconeogenesis and delaying intestinal glucose absorption (Maciel et al., 2004). As a result of the insulin metabolic disorder, changes in the synthesis of insulinoid growth factors and increased free fractions, such as IGF-I 
and IGF-II35, also occur. The discovery of a specific form of peripheral insulin resistance and the consequent hyperinsulinemia led to a connection between abnormalities of the hypothalamic-pituitary-gonadal axis (Dunaif, 1997). In high non-physiological concentrations, insulin binds to IGF-1 receptors, which are widely distributed in ovarian tissue. Then, when insulin receptors are blocked or at low number, insulin binds to IGF-1 receptors on theca cells, leading to activation of this receptor with subsequent androgen production (Speroff \& Fritz, 2005).

IGF-1 receptors are decreased in granulosa cells and increased in inner theca cells in PCOS women, thus contributing to increased hyperandrogenism (Smaniotto \& Simões, 1996). For that reason, some authors associate insulin resistance with hyperandrogenism. The decrease in peripheral insulin resistance in PCOS after the use of metformin leads to a decrease in hyperinsulinemia, which inhibits the mechanism that trigger hyperandrogenism in those patients (Speroff \& Fritz, 2005) Several authors have describe the effectiveness of treating infertility using insulin sensitizers such as metformin alone or in combination with other drugs including clomiphene citrate (Nestler et al., 1998; Vandermolen et al., 2001; Palomba et al., 2005). Moll and coworkers showed that PCOS women treated with metformin had a higher pregnancy rate and lower abortion rate (Moll et al., 2008). In another study, Lauretta et al (Lauretta et al., 2016) highlight the effect of metformin in improving the metabolic and hormonal activity of the ovaries. In the same study, the authors highlighted the importance of those sensitizers in the protection and treatment of ovarian cancer, also correlating PCOS as one of the factors that increase the risk of cancer.

Tang and coworkers compared the effect of clomiphene citrate with metformin. In subjects with a BMI $\geq 30 \mathrm{~kg} / \mathrm{m} 2$, clomiphene citrate was more efficient in facilitating pregnancy, whereas in women with a BMI $<30 \mathrm{~kg} / \mathrm{m} 2$, metformin showed better results (Tang et al., 2012). It has also been observed a reduction in the areas occupied by degenerating ovarian follicles and interstitial cells, along with the presence of corpus luteum in ovaries of PCOS rats previously androgenized and treated with metformin (Mahamed et al., 2011). The results of those previous studies are similar to our results, in which a reduction in nuclear volume and in the area occupied by interstitial cells were seen in the Met-treated groups.

In a study carried out by Ding et al., (Ding et al., 2016) higher levels of apoptosis were observed in granulosa cells in the ovaries of PCOS women. After metformin treatment, programmed cell death was regulated in obese women with insulin resistance. Our immunohistochemical findings showed that cleaved-caspase-3 immunoexpression in granulosa cells of metformin-treated rats were similar as compared to PCOS group. On the other hand, The animals from the Met1 and Met 2 groups showed a higher cleaved-caspase-3 immunoreactivity in the granulosa cells compared to the Ctrl group. Those results may be related to the increase in apoptosis of atretic follicles, which is supported by the findings of Mahamed et al.,( Mahamed et al., 2011) who also observed a decrease in the area occupied by atretic follicles in metformin-treated animals.

Metformin appears to restore morphofunctional homeostasis of the ovary, although treatment using metformin combined with other drugs appears to show better results. Accordingly, Penna suggests a combination therapy for patients with PCOS, especially those with associated obesity where standard treatment is less efficient (Penna, 2005). Our results showed that the administration of metformin improved morphological parameters both in the prevention of permanent estrus and in the treatment after the installation of permanent estrus. Further studies with different doses, combinations and duration of treatments should be performed to better elucidate the isolated and combined effects of these drugs on ovarian cells.

\section{Conclusion}

Metformin administration, before and after the induction of permanent estrus state, improved the physiological and morphological function of ovaries. The ovaries of rats treated with metformin showed a decrease in nuclear volume and in the area occupied by interstitial cells, presence of corpus luteum, in addition to a decrease in the number of cysts. 


\section{References}

Batista, J. G., Soares-Jr, J. M., Maganhin, C. C., Simões, R. S., Tomaz, G., \& Baracat, E. C. (2012). Assessing the benefits of rosiglitazone in women with polycystic ovary syndrome through its effects on insulin-like growth factor 1, insulin-like growth factor-binding protein-3 and insulin resistance: a pilot study. Clinics. 67(3):283-7. 10.6061/clinics/2012(03)14.

Ding, L., Gao, F., Zhang, M., Yan, W., Tang, R., \& Zhang, C. J. (2016). Higher PDCD4 expression is associated with obesity, insulin resistance, lipid metabolism disorders, and granulosa cell apoptosis in polycystic ovary syndrome. Fertil Steril. 105(5):1330-1337.

Dunaif, A. (1997). Insulin resistance and the polylistic ovary syndrome: mechanism and implications for pathogenesis. Endocr. Rev. 18:774-800.

Goodarzi, M. O., Dumesic, D. A., Chazenbalk, G., \& Azziz, R. (2011). Polycystic ovary syndrome: etiology, pathogenesis and diagnosis. Nat Rev Endocrinol. 7(4):219-31. 10.1038/nrendo.2010.217.

Lauretta, R., Lanzolla, G., Vici, P., Mariani, L., Moretti, C., \& Appetecchia, M. (2016). Insulin-Sensitizers, Polycystic Ovary Syndrome and Gynaecological Cancer Risk. Int J Endocrinol. 2016:8671762.

Lombardi, L. A., Simões, R. S., Maganhin, C. C., da Silva, C. F., Maciel, G. A., Baracat, E. C., et al. (2012). Morphology of the interstitial cells of rat polycystic ovaries: an experimental study. Rev Bras Ginecol Obstet. 34(7):323-8. 0.1590/S0100-72032012000700006.

Lombardi, L. A., Simões, R. S., Maganhin, C. C., Baracat, M. C., Silva-Sasso, G. R., Florencio-Silva, R., Soares Jr, J. M., \& Baracat, E. C. (2014). Immunohistochemical evaluation of proliferation, apoptosis and steroidogenic enzymes in the ovary of rats with polycystic ovary. Rev Assoc Med Bras. 60(4):349-56.

Maciel, G. A., Soares Jr, J. M., Motta, E. L. A., \& Baracat, E. C. (2004). Nonobese women with polycystic ovary syndrome respond better than obese women to treatment with metformin. Fertil Steril. 81:355-60.

Mahamed, R. R., Maganhin, C. C., Simões, R. S., De Jesus Simões, M., Baracat, E. C., \& Soares, J. M. Jr. (2011). Effects of metformin on the reproductive system of androgenized female rats. Fertil Steril. 95(4):1507-9.

Mathur, R., Alexander, C. J., Yano, J., Trivax, B., Azziz, R. (2008). Use of metformin in polycystic ovary syndrome. Am J Obstet Gynecol Reviews. 596-609.

Moll, E., Korevaar, J., Bossuyt, P. \& Van Der Veen, F. (2008). Does adding metformin to clomifene citrate lead to higher pregnancy rates in a subset of women with polycystic ovary syndrome? Human Reproduction. 23(8), 1830-1834.

Nestler, J. E., Jakubowicz, D. J., Evans, W. S., \& Pasquali, R. (1998). Effects of metformin on spontaneous and clomiphene-induced ovulation in the polycystic ovary syndrome. $N$ Engl J Med. 338:1876-80.

Olfert, E. D., Cross, B. N., \& Mcwilliam, A. A. (1993). Canadian Council on Animal Care/Guide to the Care and Use of Experimental Animals. 2nd ed. Ottawa, Ontario, Canada: Bradda Printing Services. https://www.ccac.ca/Documents/Standards/Guidelines/Experimental_Animals_Vol1.pdf.

Palomba, S., Orio, F. Jr, Falbo, A., Manguso, F., Russo, T., Cascella, T., Tolino, A., Carmina, E., Colao, A., Zullo, F. (2005). Prospective parallel randomized, doubleblind, double-dummy controlled clinicaltrial comparing clomiphene citrate and metformin as the first-line treatment for ovulation induction in non obese anovulatory women with polycystic ovary syndrome. J Clin Endocrinol Metab. 90:4068-74.

Penna, I. (2005). Acarbose in obese patients with polycystic ovarian syndrome: a double-blind, randomized,placebo-controlled study. Human Reproductio. $20(9), 2396-2401$

Qiao, J., Wang, L., Li, R., \& Zhang, X. (2008). Microarray evaluation of endometrial receptivity in Chinese women with polycystic ovary syndrome. Reprod Biomed Online. 17(3):425-35.

Sara, L., Antal, P., Masszi, G., Buday, A., Horvath, E. M., Hamar, P., et al. (2012). Arteriolar insulin resistance in a rat model of polycystic ovary syndrome. Fertil Steril. 97(2):462-8. 10.1016/j.fertnstert.2011.11.015.

Smaniotto, S., \& Simões, M. J. (1996). Morphological aspects of the endometrial epithelium of persistent estrous rats under estrogenic action. Braz J Morphol Sci. 13:103.

Speroff, L., \& Fritz, M. A. (2005). Obesity. The physiology of adipose tissue, and the problem of obesity. In: Speroff L, Fritz MA, editors. Clinical gynecologic endocrinology and infertility. Philadelphia: Lippincott Williams \& Wilkins. 779-804.

Tamimi, W., Siddiqui, Ia, Tamim, H., Aleisa, N., \& Adham, M. (2009). Effect of body mass index on clinical manifestations in patients with polycystic ovary syndrome. Int J Gynaecol Obstet. 107(1):54-7.

Tang, T., Lord, J. M., Norman, R. J., Yasmin, E., \& Balen, A. H. (2012). Insulin-sensitising drugs (metformin,rosiglitazone, pioglitazone, D-chiro-inositol) for women with polycystic ovary syndrome, oligo amenorrhoea and subfertility. Cochrane Database Syst Rev. (5):CD003053.

Vandermolen, D. T., Ratts, V. S., Evans, W. S., Stovall, D. W., Kauma, S. W., \& Nestler, J. E. (2001). Metformin increases the ovulatory rate and pregnancy rate from clomiphene citrate in patients with polycystic ovary syndrome who are resistant to clomiphene citrate alone. Fertil Steril. 75:310-5.

Zabuliene, L., \& Tutkuviene, J. (2010). Body composition and polycystic ovary syndrome. Medicina (Kaunas), 46(2):142-57. 